\title{
COOPERATION CAPABILITIES USING INDONESIAN HISTORICAL GEOGRAPHY TEXTBOOK WITH STAD STRATEGY
}

\author{
Sukma Perdana Prasetya, Sarmini, Agung Setiawan \\ Program Studi Pendidikan IPS, Jurusan Pendidikan Geografi, FISH \\ Universitas Negeri Surabaya
}

\begin{abstract}
Abstrak : Buku ajar Geografi Kesejarahan Indonesia (GKI) disusun sebagai "pemandu catatan berpikir" supaya diskusi dapat mengarah kepada pemahaman materi. Sebagai sumber pembelajaran dengan strategi cooperative learning tipe STAD, buku ajar GKI disusun untuk menyajikan subject matter yang kaya, menarik, mudah dibaca, variatif, dan disesuaikan dengan kebutuhan serta minat mahasiswa. Tujuan penelitian ini yaitu: 1) mengembangkan buku ajar yang layak, 2) mengetahui respon mahasiswa menggunakan buku ajar, dan 3) mengetahui kemampuan kerjasama mahasiswa menerapkan buku ajar dengan strategi STAD. Subjek penelitian adalah mahasiswa Pendidikan IPS, FISH, Unesa, angkatan 2020 yang memprogram mata kuliah GKI. Pengumpulan data melalui dokumentasi, observasi, dan angket. Kelayakan buku ajar GKI dinilai berdasar skala likert, sedangkan respon mahasiswa menggunakan skala Gutman. Analisis data menggunakan prosentase dan nilai rata-rata. Hasil penelitian menunjukkan: 1) penilian sangat layak, 2) Respon sangat baik dari mahasiswa yang menggunakan buku ajar GKI, dan 3). Kemampuan kerjasama mahasiswa dalam kategori cukup setelah melaksanakan pembelajaran menggunakan buku ajar GKI dengan strategi cooperative learning tipe STAD. Mahasiswa mempunyai kemampuan dalam bekerjasama dalam pembelajaran STAD tetapi tidak terlalu signifikan.

Kata kunci : kemampuan kerjasama, buku ajar, geografi kesejarahan Indoensia
\end{abstract}

Abstract: GKI textbooks are arranged into guide notes thinking so that the discussions that are applied can lead to understanding student material. As a source of learning using the STAD type of cooperative learning strategy, the GKI textbooks are structured to present rich, interesting, easy-to-read, varied, subject matter tailored to the needs and interests of students. There are 3 aims of this research, namely: 1) developing appropriate textbooks, 2) knowing student responses in using textbooks, and 3) knowing students' cooperative abilities in applying textbooks with the STAD strategy.The research subjects were Social Studies Education students, FISH, Unesa, class of 2020 who programmed the Indonesian Historical Geography (GKI) course. Data was collected using documentation, observation, and questionnaires. The feasibility of GKI textbooks is assessed according to the Likert scale, while student responses use the Gutman scale. Data analysis in this study was carried out through percentages and average values. The results showed: 1) the assessment was very feasible, 2) the response was very good from the students who used the GKI textbook, and 3). The student's cooperation ability is in the sufficient category after carrying out learning with GKI textbooks with the STAD type of cooperative learning strategy. This means that students have the ability to work together in STAD learning but it is not too significant.

Keywords: cooperation ability, textbooks, Indonesian historical geography

\section{A. INTRODUCTION}

Learning activities in addition to paying attention to cognitive aspects also need to give attention to other aspects, for example aspects of attitude in the form of: a sense of responsibility, willing to

Correspondency address: 
sacrifice, cooperation, honesty, mutual respect for opinions, and so on. In the future, it is possible for students to develop their work career paths not only in the form of getting the highest achievement score (GPA), but the ability to cooperate with other people is actually very helpful in the world of work as an effort to form a solid team work in order to achieve the goals of the institution.

Not only the world of work, in learning conditions also often show the individualistic attitude of students. Students tend to compete individually, be closed to friends, do not have empathy for friends in class, play only based on their friends of choice, want to win on their own, and so on. If this situation continues, it is not impossible to create citizens who lack respect for others, are inclusive, selfish, indifferent to neighbors and the environment, introverted, lack association in society, and cannot accept the strengths or weaknesses of others. The phenomenon of this attitude can be seen in today's society, such as how easy it is to gang up, elbow each other, fall into demonstrations, and get a little provocative. To prevent this from happening, it is necessary to apply a strategy that promotes cooperative learning.

Thus, cooperative learning is a learning strategy that needs to be implemented and gain consent and recommended by education experts. Based on that goal, it is necessary to implement a variety of learning strategies that emphasize cooperative learning. In order to optimize collaboration skills and learning outcomes, the STAD learning strategy is a cooperative learning strategy that can be chosen to be used, because it is expected to have a good impact on increasing collaboration skills and achieving understanding.

Slavin (2021), argues that cooperative learning (such as CIRC, TGT, STAD, Jigsaw) directs studentcentered learning activities and seeks the possibility of interacting and has a positive effect on students who have low understanding abilities. The findings from Suryana and Somadi (2018) say that cooperative learning type Students Team Achievment Devition (STAD): 1) has a positive impact on learning activities, 2) achieves good understanding, 3) provides special knowledge to students who are at an average level. in the high group and in the low group, 4) increased awareness among group members which may not occur if conventional learning is applied. Meanwhile, the results of Gusniar's research (2019) show that the STAD type of cooperative learning has effectiveness on cooperative abilities and learning outcomes.

The importance of cooperative learning in improving interactive and learning outcomes is also conveyed by 
Johnson and Johnson (2009), who state that socio-psychological and educational-sociological theories and research provide supporting arguments about the need to implement cooperative learning. Between theory and studies in the practice of everyday learning at school, students are not only required to be the number one child in class, study hard to be a star in class, study individually to achieve the highest achievement.

In cooperative learning activities, students are asked and directed to work together, help each other between friends who have problems in learning, interact with group members in order to gain a common understanding, and finally achieve mutual success. This joint success is the main concern in cooperative learning so that in the future, students can carry out other activities through the process of working together.

In addition to learning strategies, learning media are also needed to optimize learning activities (Reigeluth, 2017). One of the learning media that can be used as a component in learning is textbooks. So far, in the course of Geografi Kesejarahan Indoensia (GKI) or Indonesian Historical Geography the textbook has not been developed. GKI learning still uses media that have not been systematized in a textbook.

GKI textbooks are prepared as guide notes thinking so that the discussion activities carried out can lead to material that students are expected to understand. GKI textbooks facilitate independent learning activities and work together in groups, both regarding substance and presentation. The GKI textbooks are compiled based on the standard books for the social studies field, so that the GKI textbooks are prepared to provide a source of knowledge that is systemically structured, organized, and has sufficient depth in its presentation.

As a source of learning in cooperative learning strategies, GKI textbooks are structured to provide rich, easy-to-read and varied subject matter, and are tailored to the needs and interests of students. As a basic foundation for various activity programs, it is recommended that collaboration skills be obtained in dynamic discussion conditions and provide an important initial appearance, as well as support for practical assignments and exercises.

The preparation of university textbooks includes aspects of (a) courses (subjects), (b) learning planning, (c) approaches/models/strategies/learning methods, and (d) validation, learning 
materials, and learning media presented. When a schematic is created, it can be seen in Figure 1.

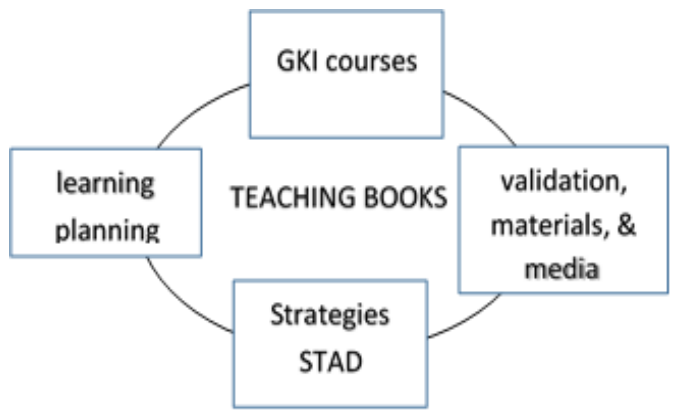

Figure 1. The application of cooperative learning with textbooks in the GKI course

In the implementation of the STAD-type cooperative learning strategy with the help of the GKI textbook, the lecturer acts as a facilitator so that learning that takes place can involve students in group activities consisting of four to five students. The group members formed are composed of various kinds of diversity such as intelligence, religion, gender, race/ethnicity, performance level, and other characteristics of students (Slavin, 2021).

Through various differentiations of group members, each group member can help each other to solve difficulties together (cooperatively) in order to achieve learning objectives. In cooperative learning, the assignment is not just carrying out an individual activity but being responsible to a team, learning for the sake of achieving mutual success.
Thus, each student as a team member is able to learn to place themselves and implement cooperative values and attitudes in a learning organization. The objectives of this research activity are: 1) to compile a textbook of Indonesian Historical Geography (GKI) that is suitable for use 2 ) to test the effectiveness of the use of the GKI textbook on the ability to cooperate in the STAD strategy.

\section{B. METHOD}

This type of research is quasiexperimental. Quasi experiments are applied considering that not all variables that can affect learning outcomes can be checked strictly as in true experiments carried out in the laboratory. Quasiexperimental research has the aim of proving the effect of the independent variable on the dependent variable. In this study, Social Studies Education students became the research subjects, while the application of the GKI textbook was a treatment applied to the subject.

This research design is designed as follows (adapted from Tuckman, 1999):

\section{$\mathrm{X}-\mathrm{O}$}

Information:

$\mathrm{X}=\mathrm{STAD}$ type textbook

$\mathrm{O}=$ observation (student response and collaboration skills)

The research subjects were Social Studies Education students, Faculty of 
Social Sciences and Law, State University of Surabaya, class of 2020 who programmed the Indonesian Historical Geography Learning (GKI) course of 16 students through the application of textbooks with the STAD type. The application of student lectures is limited due to the COVID-19 pandemic, so Face-to-face Lectures (PTM) activities are limited to students who live in Surabaya, Gresik and Sidoarjo.

Data was collected using the following methods: documentation, observation, and questionnaires. The feasibility of the GKI textbooks was assessed using a Likert scale by an expert validator, while student responses used the Gutman scale. After being declared eligible, textbooks are used in lecture activities. This study applies the treatment of textbooks with cooperative learning type STAD. Based on the type of research variables, the data analysis technique used is descriptive quantitative. To analyze the data in this research is done through the percentage and average value.

\section{RESULTS AND DISCUSSION C.1. RESULT \\ 1). Teaching Book Eligibility}

The quality of the study book of Indonesian Historical Geography is oriented to cooperative learning strategies to improve cooperation capabilities. The quality of the product eligibility of indoensia historical geography (GKI) study is assessed based on the assessment of validators and their use. Validator assessment is seen from material aspects, language, presentation and radiography. The quality of its use is assessed by the student's response..

Table 1. Validation of Material Feasibility

\begin{tabular}{llc}
\hline No & \multicolumn{1}{c}{ Assessment Aspects } & $\begin{array}{c}\text { Rating } \\
\text { Score }\end{array}$ \\
\hline $\mathbf{1}$ & Material: covers (1) breadth (2) depth & 5 \\
\hline $\mathbf{2}$ & $\begin{array}{l}\text { The accuracy of the material includes: (1) actual/conceptual } \\
\text { accuracy and (2) accuracy of illustrations }\end{array}$ & 4 \\
\hline $\mathbf{3}$ & Conformity with scientific development & 5 \\
\hline $\mathbf{4}$ & Current in the presentation of teaching books on features & 3 \\
\hline $\mathbf{5}$ & Accompanied by an example & 4 \\
\hline $\mathbf{6}$ & referral list update & 5 \\
\hline $\mathbf{7}$ & $\begin{array}{l}\text { Based on empirical concepts, theories, and facts that can be } \\
\text { accounted for }\end{array}$ & 4 \\
\hline & Average & 4,28 \\
\hline & & source: primary data 2021 \\
& Overall, the material feasibility & 4.28 from the material validator. The \\
component obtained an average score of & conclusion of the validation results is that
\end{tabular}


the GKI textbooks compiled in the category and can be used in lectures research are included in the very feasible without any revision.

Table 2. Validator results from media experts

\begin{tabular}{|c|c|c|}
\hline No & Assessment Aspects & $\begin{array}{c}\text { Rating } \\
\text { Score }\end{array}$ \\
\hline 1 & $\begin{array}{l}\text { Presentation techniques include: (1) the edressing of concepts; (2) } \\
\text { consistent systematics and (3) balance between chapters }\end{array}$ & 5 \\
\hline 2 & $\begin{array}{l}\text { The presentation of learning includes: (1) student-centered; (2) } \\
\text { develop process skills }\end{array}$ & 4 \\
\hline 3 & $\begin{array}{l}\text { Completeness of presentation includes: (1) boating; (2) table of } \\
\text { contents; (3) glossary; (4) bibliography; (5) summary and concept } \\
\text { map; (6) Evaluation }\end{array}$ & 4 \\
\hline 4 & Proportional text and images are harmonious & 5 \\
\hline 5 & Accompanied by an example & 4 \\
\hline \multirow[t]{2}{*}{6} & $\begin{array}{l}\text { Illustration provides support to learning activities and message } \\
\text { delivery }\end{array}$ & 4 \\
\hline & Average & 4,33 \\
\hline
\end{tabular}

Media feasibility experts assess the GKI course textbooks with an average result of 4.33 which can be categorized as very feasible. Furthermore, media experts recommend that textbooks can be used in learning activities for GKI courses.

The conclusion of the general assessment from the material and media expert validators is that the GKI textbooks compiled in the research are very feasible and can be applied to lectures without any further revisions.

\section{2). Student Response}

After the GKI textbooks are declared feasible by the validator, then the textbooks are applied in learning with the STAD strategy. The next step is that students are asked to respond based on the learning activities that have been carried out. The following is a table of student responses after carrying out learning with GKI textbooks through the STAD strategy.

The results of student responses or responses to the use of GKI textbooks get a score of $85.94 \%$. Based on the results of these scores, it can be said that the GKI textbooks are classified as very good to be applied in lectures 
Table 3. Student Response Results in Implementing Teaching Books

\begin{tabular}{llcccc}
\hline No & \multicolumn{1}{c}{ Student response } & \multicolumn{3}{c}{ Information } \\
& Yes & $\mathbf{\%}$ & No & \% \\
\hline 1 & Students enjoy reading material in GKI teaching books & 14 & 87,5 & 2 & 12,5 \\
\hline 2 & Students are interested in reading other materials & 13 & 81,25 & 3 & 18,75 \\
\hline 3 & $\begin{array}{l}\text { Students are interested in learning the material after reading } \\
\text { the material in the GKI teaching book }\end{array}$ & 16 & 100 & 0 & 0 \\
& & & & \\
\hline 4 & $\begin{array}{l}\text { Students love the visualization contained in GKI teaching } \\
\text { books }\end{array}$ & 14 & 87,5 & 2 & 12,5 \\
\hline 5 & $\begin{array}{l}\text { Students gain new knowledge after reading GKI teaching } \\
\text { books }\end{array}$ & 13 & 81,25 & 3 & 18,75 \\
\hline 6 & Students like the typefaces displayed in GKI teaching books & 14 & 87,5 & 2 & 12,5 \\
\hline 7 & $\begin{array}{l}\text { Students understand the contents of the material displayed } \\
\text { in the GKI teaching book }\end{array}$ & 12 & 75 & 4 & 25 \\
\hline 8 & Students gain new knowledge from GKI teaching books & 14 & 87,5 & 2 & 12,5 \\
\hline & Average & & 85,94 & 14,06 \\
\hline & & Source: primary data & 2021
\end{tabular}

\section{3) Cooperation Capabilities}

The research was carried out on social studies education students who programmed the GKI course. The application of the GKI textbook was carried out on September 20 - October 2021, using limited face-to-face lectures (PTM) for 3 meetings. The value obtained is in the form of an average score from the observation of students' cooperative abilities using a Likert scale. The ability of student cooperation is observed when students in groups make learning by using GKI textbooks and using cooperative learning strategies of the STAD type. The results of the calculation of students' cooperative abilities in each aspect can be seen in Table 4.

Table 4. Recap aspects of student cooperation

\begin{tabular}{clc}
\hline No & Aspects of Cooperation & Average score \\
\hline 1 & Togetherness & 3,25 \\
\hline 2 & Discussion & 3,75 \\
\hline 3 & Argue & 3,56 \\
\hline 4 & Compactness & 2,95 \\
\hline & Total Average & 3.38 \\
\hline & & Source: primary data 2021
\end{tabular}

There are four aspects of the average score of students' ability to cooperate, with details: 1) togetherness gets an average of $3.25 ; 2$ ) the discussion got an average of $3.75 ; 3$ ) believes that it gets an average of 3.56 ; 4) compactness got an average of 2.95. The average total aspect of cooperation gets a score of 3.38 


\section{C.2. DISCUSSION}

The preparation of the GKI textbooks that were compiled contained many examples of texts that were studied by students. The sample text is given as a medium for student reading activities. Thus, the sample text presented is an authentic text. This is like the opinion of Crawford (2012), that when developing textbooks, learning activities need to pay attention to the presentation of authentic text examples.

The results of the feasibility assessment given by the experts showed that the GKI textbooks that had been compiled from a conceptual point of view of the material and media experts could be accounted for and were categorized as very feasible without revision. This means that according to the validation assessment of experts, the textbooks that have been compiled are included in the category suitable for use. This is an absolute requirement in the textbook that must be met so that it can be used for the benefit of implementing learning activities. According to Prasetya et al.(2018), the feasibility of an expert validator is the main requirement for developing a textbook to be applied in learning.

Response questionnaires were given to students after they used the GKI textbook. Referring to the results of the data recap from the questionnaire that has been given to students, it shows that student responses regarding the use of GKI textbooks are in the very good category. This shows that although the cooperative ability obtained from the use of GKI textbooks is in sufficient category, but in terms of using GKI textbooks as learning resources, students respond very well.

Based on the average results of lectures for three times using the GKI textbook and the STAD strategy, the cooperative ability score was 3.30 so it was categorized as sufficient. According to Sarwanto in Maasawet (2011) refers to using a Likert scale in the range of 1 to 5, at an average value of $3 X<4$ it is said to be sufficient to cooperate with one member of the group or in a good position as a member of the group.

This STAD type of cooperative learning strategy is used for students as a learning activity in practicing cooperative skills. Through the STAD strategy, students undergo lectures leading to the ability to understand the material through responsibilities in achieving common goals. Through the STAD strategy students will face a relevant assignment to be completed either through group discussion so that they can solve problems and draw conclusions together (Prasetya, 2014).

GKI lectures facilitate students to achieve the ability to cooperate in lectures. This is because the GKI lectures carried out so far are still practicing 
traditional patterns in their learning. The lecture practice applied, in fact, there has been no attempt by the lecturer to direct students to work together when the GKI course is delivered. The most essential thing in cooperative learning is how to teach students to achieve the ability to work together. The same thing with the findings of Altun (2015), that cooperative learning strategies have a positive impact on the achievement of affective and social abilities.

The results of this study illustrate that the application of the GKI textbook with a cooperative strategy of the STAD type is quite capable of providing cooperative abilities for students. The ability to cooperate is one of the four important competencies in addition to the ability to think critically, creatively and communicate. According to Hurlock (in Fauziddin, 2016), the ability to cooperate is one of the competencies in social behavior patterns. For students who have more and more opportunities to carry out and complete a job together, the faster students learn to carry out their work through collaborative ways.

\section{CONCLUSION}

1. The GKI textbooks that have been compiled have met the feasibility according to the reviews of material experts and media experts.

2. Student response to the use of GKI textbooks as a learning resource for the lecture process was very well received by students. This can be seen based on the recap of the analysis of student responses getting a percentage of $85.94 \%$, where holding on to the Likert scale is categorized as very good.

3. The implementation of the GKI textbook with the STAD type of cooperative learning strategy, in a categorical manner, is quite capable of providing students with the ability to cooperate.

\section{BIBLIOGRAPHY}

Altun, S. 2015. The Effect of Cooperative Learning on Students Achievement and Views on the Science and Technology Course. International Electronic Journal of Elementary Education. 7(3): 451-468.

Crawford, J. 2012. "The Role A Material in Language Classroom." In Richard, J.C, \& Renandya, W.A. (Eds.). Methodology in Language Teaching: An Anthology of Current Practice. Cambridge: Cambridge University Press.

Fauziddin M. 2016. Increasing Cooperation Capability through Group Work Activities in Children Group A Kindergarten Kartika Salo Kampar Regency. Jurnal PGPAUD STKIP PTT. 2 (1). 29 45.

Gusniar. 2019. Penerapan Model Pembelajaran STAD Dalam Meningkatkan Hasil Belajar Siswa 
Pada Mata Pelajaran IPS. Jurnal

Kreatif Tadulako. 2 (1). 198 - 221. Johnson, D.W dan Johnson R.T. 2009.

Cooperative Learning Institute \& Interaction. Book Retrieved 1 March, 2018 from http://www.cooperation.org/?page_id=6

Maasawet E.T. 2011. Improving The Ability of Biological Learning Cooperation Through the Application of Guided Inquiry Strategies in Students of Class VII State Junior High School VI Samarinda City Year of Study 2010 / 2011. Bioedukasi. 2 (1).

Prasetya S.P. 2014. Memfasiltasi pembelajaran berpusat pada siswa. Jurnal Geografi dan Pengajarannya. 12 (1), 1-12.

Prasetya S.P, Daryono, Murtedjo. 2018. The Effect of Teachingbooks and Prior Knowledge on Learning Outcome of Geography. Advances in Social Science, Education and Humanities Research. Volume 226. 440-445.

Pratiwi I.A, Ardianti S.D, Kanzunnudin M. 2018. Peningkatan Kemampuan Kerjasama Melalui Model Project Based Learning (PjBL) Berbantuan Metode Edutainment Pada Mata Pelajaran Ilmu Pengetahuan Sosial. Jurnal Refleksi Edukatika . 8 (2). 177182.

Reigeluth. 2017. Instructional-Design Theories and Models: Volume IV, The Learner-Centered Paradigm of Education. New York: Routledge.

Slavin, R.E. 2021. Educational Psychology. Edition 9 Volume 2.New Jersey : New Jersey Pearson Education Inc. Publishings Allyn \& Bacon

Solehun, Yulianto B, Suhartono. 2017. Pengembangan Buku Ajar Mata Kuliah Bahasa Indonesia Berorientasi Pendekatan Saintifik Untuk Meningkatkan Kompetensi Mahasiswa S1 PGSD. Jurnal Review Pendidikan Dasar: Jurnal Kajian Pendidikan dan Hasil Penelitian. 3 (1). 329-338.

Suryana, Y. R dan Somadi, T.J. 2018. Kajian Model Pembelajaran Kooperatif Tipe STAD (Student TeamsAchievement Division) Dalam Upaya Meningkatkan Efektifitas Proses Belajar Mengajar Akuntansi. Oikos: Jurnal Kajian Pendidikan Ekonomi dan Ilmu Ekonomi. II (2). 133- 145.

Tuckman, B. W. 1999. Conducting educational research. Fifth Edition. New York: Harcourt Brace College Publisher 